\title{
MODEL INTEGRATED TOTAL QUALITY MANAGEMENT DI SEKOLAH BERBASIS PESANTREN
}

\author{
Ahmad Yusuf \\ Universitas Wahid Hasyim Semarang \\ Email: yusuf_jpa@yahoo.com
}

\begin{abstract}
ABSTRAK
Artikel ini bertujuan mendeskripsikan bagaimana model Integrated Total Quality Management (ITQM) di Sekolah Berbasis Pesantren. Dengan menggunakan model penelitian Research and Development $(R \& D)$ dalam kerangka pendekatan kualitatif. Hasil dari penelitian ini yaitu model Integrated Total Quality Management di Sekolah Berbasis Pesantren hanya dapat dibangun atas dasar komitmen antara sistem manajemen Pesantren,Yayasan dan sekolah memiliki keselarasan visi,misi dan tujuan.ketiga manajerial tersebut tetap menjalankan proses quality planning, quality organizing, quality actuating dan quaity controlling dalam setiap proses manajemen dan saling terkoordinasi dengan baik sehingga tidak terjadi overlapping kebijakan dan program. Komitmen ketiga manajemen selalu berusaha mencari peluang untuk integrasi manajemen yang lebih efisien dan efektif dalam meningkatan mutu pendidikan dan berfokus pada kepuasan pelanggan dan perbaikan berkelanjutan.
\end{abstract}

Kata kunci: ITQM, integrasi manajemen, Sekolah Berbasis Pesantren

\begin{abstract}
This article aims to describe how the Integrated Total Quality Management (ITQM) model in Pesantren-Based Schools. By using the Research and Development $(R \& D)$ research model within the framework of a qualitative approach. The result of this research is that the Integrated Total Quality Management (ITQM) model in Pesantren-Based Schools can only be built on the basis of a commitment among the management system of the Pesantren (Islamic Boarding School), the Foundation and the school having an alignment of vision, mission and goals. The three managerial processes persistently to carry out quality planning, quality organizing, quality actuating and quality controlling in every management process and well coordinated with each other so that there is no overlapping of policies and programs. The third commitment of management is always to seek opportunities for more efficient and effective integrated management in improving the quality of education and focusing on customer satisfaction and continuous improvement.
\end{abstract}

Keywords: ITQM, integrated management, Pesantren-Based Schools. 


\section{PENDAHULUAN}

Manusia adalah makhluk yang memiliki dual dimensi fungsional,yaitu individual dan sosial.dalam menjalankan fungsinya sebagai individual segala sesuatu yang dilakukan adalah tanggung jawabnya dan dia sendiri yang akan menerima segala konsekuensi atas perbuatannya. Fungsi individual ini termasuk pengembangan dirinya, eksistensi dirinya sampai kepada kewajibannya kepada Tuhannya (Ibadah). Sedangkan dimensi fungsi sosialnya akan selalu berhubungan dan berimbas pada individu lainnya atau masyarakat bahkan antar makhluk secara makro. Dalam melaksanakan fungsinya sebagai makhluk sosial inilah manusia hendaknya selelu mempertimbangkan segala tindakan, pemikiran bahkan dalam bersikap terhadapa makhluk lainnya karena apa yang diperbuat akan menimbulkan konsekuensi logis pada diri orang lain pula dan lingkungannya.

Hal ini dapat difahami manusia tidak bisa terlepas dari dinamika kehidupan yang melingkupinya, sosial dan perkumpulan baik formal maupun non formal. Sebuah organisasi, baik skala kecil maupun besar, profit oriented ataupun non profit oriented merupakan keniscayaan untuk menjadikan sistem manajemen menjadi ruh dan sarana dalam merealisasikan tercapainya tujuan. secara garis besar sistem manajemen yang terkenal adalah dengan rumus POAC (Planning, Organizing,actuating and controlling).

Ada juga pendapat tentang kerangka kerja manajemen adalah Planning, Organizing, Leading dan controlling sebagaimana yang dikemukakan oleh Mason A. Carpenter dkk dalam bukunya “Management Principles”. Selanjutnya Mason mengansumsikan bahwa tantanagan utama seorang manager atau pemimpin adalah memecahkan masalah dengan creative. Disisi lain menggambarkan dari berbagai disiplin ilmu, dan yang dapat membantu seorang manajer mampu merespon tantangan- tantangan tersebut adalah prinsip prinsip manajemen yang digolongkan menjadi empat fungsi utama yaitu Palnning, Organizing,Leading dan Controlling (POLC Framework). ${ }^{1}$

Dengan demikian kerangka kerja atau fungsi utama manjaen yang ditawarkan oleh Mason dkk adalah Planning, Organizing, Leading dan Controlling (POLC). Jika diperhatikan ada kemiripan istilah dalam kerangka kerja manajemen ini dengan konsep yang ditawarkan oleh George $\mathrm{R}$ Terry (POAC) hanya saja pada istilah "Leading” dan " Actuating ". Menurut hemat penulis itu hanya perbedaan istilah. bukanlah suatu hal yang kontra dalam makna melainkan perbedaan istilah itu hanya pada kata saja sehingga makna yang terkandung tetap sama dalam fungsi. Actuating identik dengan peran utama pemimpin secara komprehensif untuk menggerakkan seluruh komponen dalam

\footnotetext{
${ }^{1}$ Mason A. Carpenter, Management Principles (Creative Commons by-nc-sa 3.0, n.d.), 27 , http://creativecommons.org/licenses/by-nc-sa/3.0/).
} 
kelompok organisasi. Sedangkan kata leading ini lebih eksplisit yang diambil dari kata lead-leading-leader. Sehingga penulis mengasumsikan actuating sama makna dengan leading.

Pengelolaan lembaga pendidikan di semua jenjang dewasa ini menjadi suatu yang urgen dan menarik untuk didiskusikan. Hal ini tak lain karena semakin kompleksnya kepentingan, kebutuhan dan tantangan zaman yang semakin sulit diprediksi karena saking cepatnya perubahan itu. Salah satu usaha untuk merespon arus perubahan itu adalah melalui sistem manajemen yang matang. Lembaga pendidikan terus menjadi tolok ukur dalam kemajuan suatu bangsa di dunia ini. Pernyataan ini bukanlah hal yang berlebihan karena tidak dapat dipungkiri bahwa proses pendidikan yang bermutu dapat melahirkan generasi yang berkualitas pula.

Proses pendidikan yang efektif dan efisien akan menjadikan lembaga yang berkualitas. Banyak lembaga pendidikan yang gulung tikar atau merger dengan lembaga lain karena kekurangan siswa. Tidak sedikit pula sekolah/ madrasah yang hanya sekedar bertahan tanpa memapu menunjukkan kemajuan yang sgnifikan, dengan istilah lain " Laa yahyaa wa laa yamuutu ". Realita ini tentu mengundang keprihatinan dari semua pihak. Tak terkecuali dari kalangan ahli pendidikan dan akademisi untuk mengkajinya dengan tujuan mencari solusi yang tepat secara keseluruhan masalah klasik yang terjadi Persoalan manajemen memang bukanlah satu-satunya faktor penentu kemajuan lembaga pendidikan. Akan tetapi sistem manajamen yang dijalankan di lembaga tersebut sangat berpengaruh terhadap mutu dari pendidikan.

Terwujudnya sebuah lembaga pendidikan yang bermututidak semudah membalikkan telapak tangan. Butuh tanggung jawab yang kuat dan orientasi mutu dari semua pihak, baik sekolah, masyarakat, dunia usaha dan stakeholder lainnya. Pendidikan memiliki internal customer dan external customer yang keduanya dapat menjadi barometer mutu proses pendidikannya. Mutu pendidikan dapat terwujud dengan adanya kerjasama dan kolaborasi semua pihak. Meskipun demikian peranan manajemensekolah sangat penting dan dominan dalam menentukan keberhasilan sekolah. Aspek-aspek dan potensi yang ada dalam lembaga sudah semestinya saling berinteraksi dan memiliki orientasi yang sama yaitu pada pengembangan mutu pendidikan sesuai dengan visi dan misi sekolah.

Sekolah layaknya perusahaan yang menghasilkan produk pendidikan yang bermutu, sumber daya manusia yang memiliki kompetensi dan daya saing sejalan dengan tuntutan zaman. Dalam pandangan Suryadi Poerwanegara terdapat beberapa komponen mendasar yang dapat mempengaruhi kualitas hasil atau produk. Adapun komponen-komponen tersebut adalah, manusia, metode, mesin, 
bahan, ukuran (measurement) dan evaluasi berkelanjutan. ${ }^{2}$. Terkait dengan upaya meningkatkan mutu pendidikan ini beberapa penelitian menunjukkan bahwa setidaknya $85 \%$ persoalan muncu dan berkutat pada sistem manajemen yang dijalankan. Manajemen yang baik dapat mengantarkan sebuah organisasi ke arah pencapaian tujuan dengan efektif dan efisien. Model manajemen yang diimplementasikan sangat berpengaruh pada mutu hasil. Salah satu model manajemen yang telah terbukti keberhasialannya dalam meningkatkan mutu produk di berbagai industri adalah model TQM (Total Quality Management). Model manajemen yang berorientasi mutu ini kemudian dilirik dunia pendidikan diadopsi dan diadaptasikan serta diimplementasikan dalam sistem manajemen sekolah yang familiar disebut dengan istilah Total Quality management in Education (TQME). Melalui TQME ini dunia pendidikan semakin sistematis terarah dalam meningkatkan mutu pendidikan dengan selalu berupaya memaksimalkan daya saing sekolah melalui perbaikan yang terus menerus untuk memenuhi kepuasan pelanggan (pengguna lulusan). Sekolah semakin dapat memberikan kontribusi terhadap lingkungannya. ${ }^{3}$

Tidak dapat disangkal bahwa manajemen merupakan satu sistem yang cukup prinsipil dalam segala aspek kehidupan manusia, terutama dalam lembaga pendidikan agar tujuan (visi dan misi) tercapai secara efektif dan efisien. Terkait dengan pentingnya manajemen dalam lembaga pendidikan, dalam maklah ini peuulis mencoba memaparkan system manajemen kurikulum, SDM dan Sarana \& prasarana dalam konsep Total Quality Management.

Fakta yang ada di SMP Berbasis Pesantren Jepara dapat dikatakan cukup banyak, di antaranya adanya pondok pesantren, kurikulum pondok dan kurikulum nasional yang terintegrasi, tenaga pendidik dan kependidikan yang berkompeten, sarana-prasarana yang cukup serta lingkungan sekolah yang cukup kondusif. Akan tetapi potensi-potensi yang ada belum mampu diberdayakan secara maksimal. Hal ini disebabkan masih belum terkoordinasi dengan baik antara pengelola manajemen Pesantren,Yayasan dan Sekolah. Dengan kata lain faktor utama yang menhambat perkembangan dan peningkatan mutu pendidkan yaitu dari sistem manajemen yang belum mampu mengintegrasikan dan mensinergikan manajemen pondok pesantren, manajemen yayasan serta Manajemen Sekolah, Sehingga terkesan adanya dualisme visi, misi.dan tujuan. Terjadi duplikasi kebijakan dan program. Begitupun dalam hal kurikulum belum secara harmonis terintegrasi dengan efektif. Masih terkesan menggabungkan pelajaran pondok pesantren dengan pelajaran sekolah umum. Pada hal hakikatnya integrasi bukan sekedar menggabungkan namun saling mengisi, melengkapi dan bersinergi antar

2 Suryadi Prawirosentono, Filosofi Baru Tentang Manajemen Mutu Terpadu (Jakarta: PT.Bumi Aksara, 2002), 12.

${ }^{3}$ MN. Nasution, Manajemen Mutu Terpadu (Jakarta: Ghalia Indonesia, 2000), 28. 
keduanya sehingga menjadi kesatuan ilmu yang utuh bagi peserta didiknya. Oleh karena penting bagi penulis untuk melakukan penelitian yang mencoba menemukan produk desain prosedural sebuah konsep pengembangan Model Integrated Total Quality Managememnt (ITQM) di SMP Berbasis Pesantren ini.

\section{METODE PENELITIAN}

Penelitian yang digunakan dalam artikel adalah penelitian Research and Development $(R \& D)$ deskripsi, dengan pendekatan kualitatif. Penelitian dan pengembangan (Research and Development/R\&D) adalah sebuah metode penelitian yang bertujuan untuk menghasilkan produk tertentu dan kemudian menguji efektifitas dari produk tersebut. ${ }^{4}$

Penelitian ini berusaha menghasilkan produk berupa design pengembangan model Integrated Total Quality Management (ITQM) SMP Berbasis Pesantren.

\section{PEMBAHASAN DAN HASIL PENELITIAN}

\section{Konsep Dasas Sistem Manajemen Mutu ( Total Quality Management )}

Secara singkat kerangka kerja manajemen adalah Planning, Organizing, Leading dan controlling sebagaimana yang dikemukakan oleh Mason A. Carpenter dkk dalam bukunya " Management Principles". Selanjutnya Mason mengansumsikan bahwa tantanagan utama seorang manager atau pemimpin adalah memecahkan masalah dengan creative. Disisi lain menggambarkan dari berbagai disiplin ilmu, dan yang dapat membantu seorang manajer mampu merespon tantangan-tantangan tersebut adalah prinsip-prinsip manajemen yang terbagi ke dalam empat fungsi utama yaitu Planning, Organizing,Leading dan Controlling. ( P-O-L-C Framework). ${ }^{5}$

Terminologi manajemen mutu dalam pendidikan mencuat ketika Sallis Edward mengembangkan sebuah prinsip manajemen yang lazim berlaku di perusahaan industri namun ia memodifikasinya untuk dijalankan di lembaga pendidikan. Konsep Total Quality Management ini merupakan sebuah pendekatan filosofis yang memegang prinsip perbaikan terus menerus dalam pendidikan. Lembaga pendidikan dapat memberikan seperangkat alat praktis ntuk mewujudkan kepuasan pelanggannya karena kebutuhan pelanggaan terpenuhi, merujuk pada definisi ini dapat ditarik menjadi dua konsep utama yaitu; sebagai filosofi perbaikan terus menerus (continuous improvement) dan sistem yang berkaitan dengan alat-alat serta teknik yang dilakukan untuk memperbaiki kualitas hasilyang dibutuhkan oleh pelanggan/ masyarakat.

\footnotetext{
${ }^{4}$ Sugiyono, Metode Penelitian Pendidikan; Pendekatan Kuantitatif, Kualitatif, Dan R\&D (Bandung: Alfabeta, 2016), 407.

${ }^{5}$ Mason A. Carpenter, Management Principles, 27.
} 
Total Quality Management sebagai strategi untuk menanamkan kesadaran atas kualitas proses dalam sebuah organisasi. TQM juga sebagai filosofi dan metodologi yang dapat membantu meningkatkan kesadaran mutu. Perubahan perilaku organisasi menjadi inti dari pendekatan TQM ini. Selamet memberikan penegasan mengenai TQMini yaitu lebih pada prosedur di mana setiap orang dalam organisasi berusaha semaksimal mungkin memperbaiki proses-proses menuju keberhasilan organisasi. TQM bukan sekedar peraturan ataupun ketentuan yang rigid, namun lebih berperan sebagai proses dan prosedur perbikan kinerja masing-masing elemen organisasi sehingga tercipta keselarasan upaya dari masing-masing elemen. Kondisi ini akan berimbas besar pada kesiapan dan motivasi semua anggota organisasi dalam kinerjanya dan menghadapi tugastugasnya dengan penuh tanggungjawab. ${ }^{6}$

International Organization for Standardsization yang kerap disingkat ISO merumuskan sistem manajemen mutu ini dengan sistem penetapan kebijakan, sasaran, dan pencapaian secara langsung dan terkontrol dalam sebuah organisasi yang dapat mempengaruhi kualitas. Dalam standard ini dikemukakan beberapa standar mutu yang meliputi:

1. Adanya orientasi utama pada peningkatan mutu yang mencakup pada kebijakan, perencanaan, sasaran yang jelas, prosedur yang sistematis, instruksi kerja serta jejak rekam mutu.

2. Adanya garansi atau keterjaminan standar dilaksanakannya manajemen mutu, terpantau dengan baik, dievaluasi dan diperbaiki secara kontinu

3. Adanya penjaminan pada peningkatan mutu yang berkesinambungan melalui proses pelayanan, produksi maupun standar manajemen mutu itu sendiri. ${ }^{7}$

Dengan menerapkan TQM bukan berarti kita bekerja untuk agenda orang lain atau pelanggan, kecuali lembaga tersebut sudah ada kesepakatan dengan pelanggan sehingga harus memenuhi atau memberikan kepuasan kepada pelanggan. Dalam hal ini Sallis mengemukakan

The total in TQM dictates that everything and everybody in theorganization is involved in the enterprise of continuous improvement.

The management in TQM likewise means everyone, because everyonein the institution whatever their status, position or role is the manager of their own responsibilities ${ }^{8}$

\footnotetext{
${ }^{6}$ Sulipan, "Manajemen Mutu Pendidikan," wordpress.com, n.d.

${ }^{7}$ https://www.wikiapbn.org/sistem-manajemen-mutu/ diakses pada tanggal 16 November 2019 pukul 11.45 WIB

${ }^{8}$ Edward Sallis, Total Quality Management in Education, 3rd ed. (London: Kogan Page Ltd, 2002), 24.
} 
Dari pernyataan tersebut dapat difahami bahwa kunci dari TQM adalah kemampuan seorang manajer / leader dalam melibatkan semua komponen organisasi apapun statusnya. Dalam TQM yang semua orang bertanggung jawab untuk melakukan perbaikan secara berkelanjutan.

\section{Ruang Lingkup Total Quality Management dalam Pendidikan}

Prinsip dasar dalam manajemen meningkatkan mutu sebuah perusahaan atau organisasi adalah dengan memperhatikan elemen-elemen dan potensi yang dimiliki oleh organisasi. Elemen dan potensi ini menjadi pilar dalam mendesain sistem manajemen yang berorientas mutu organisasi. Beberapa hal yang erlu diperhatikan adalah visi dan misi organisasi, mengeliminir hambatan-hambatan, membangun komunikasi yang efektif, serta melakukan evaluasi berkesinambungan. ${ }^{9}$

Sedangkan menurut Sallis, ada beberapa hal yang perlu diperhatikan dalam mengimplementasikan TQM diantaranya adalah sebagai berikut:

1. Perbaikan berkelanjutan (Continuous improvement)

2. Perubahan budaya/perilaku organisasi (changing culture)

3. Organisasi yang terbalik (The Upside-down organization)

4. Memelihara hubungan dekat dengan pelanggan (keeping close to the customers)

5. Pelanggan internal (internal cutomers)

6. Pemasaran internal(internal marking)

7. Profesionalisme (professionalism)

8. Kualitas pembelajaran (the quality of learning) ${ }^{10}$

\section{Faktor faktor dominan dalam Sistem Total Quality Management}

Berbicara tentang faktor yang mempengaruhi TQM dapat merujuk pada standar manajemen mutu pada penerapan delapan prinsip manajemen mutu yang merupakan dasar penerapan sistem manajemen mutu ISO 9001:2008, yaitu:

1. Fokus pada pelanggan (Costumer Focus)

Tidak dapat dipungkiri bahwa eksistensi organisasi bergantung pada pelanggan atau pengguna produk organisasi tersebut. Semakin tinggi kemampuan organisasi dalam memebrikan kepuasan pada pelanggannya akan semakin tinggi pula loyalitas pelanggan kepada organisasi tersebut. Sehingga bukan suatu hal yang berlebihan ketika organisasi atau perusahaan berusaha memahami tuntutan dan harapan dari pelanggannya dan kemudian mengupayakan untuk terpenuhinya bahkan terlampauinya ekspektasi pelanggannya.

9 Vincent Gaspersz, Total Quality Management (Jakarta: PT Gramedia Pustaka Utama, 2008), 226

${ }^{10}$ Sallis, Total Quality Management in Education, 25-31. 
Sebagaimana Syafarudin dalam Wahyuli Lius Zen mengemukakan bahwa indikator keberhasilan penerapan manajemen mutu di sekolah dilihat dari tingkat kepuasan pelanggan internal maupun eksternal. Adapun indikator-indikator tersebut dapat dilihat pada aspek-aspek berikut ini:

a. Kepuasan siswa atas pelayanan sekolah

b. Kepuasan orang tua pada sekolah dalam melayani/melaksanakan pendidikan untuk anaknya

c. Kepuasan pengguna ataupun penerima output sekolah (lulusan) yang memiliki mutu kompetensi sesuai harapan bahakan melampaui harapan

d. Kepuasan guru dan karyawan dengan layanan sekolah. ${ }^{11}$

\section{Kepemimpinan (Leadership)}

Pemimpin tak ubahnya sebagai komando ataupun nahkoda dalam sebuah kapal. Berhasil dan tidaknya sebuah kapal melalui hambatan dan sampai pada tujuan bertumpu pada ketepatan komando, arahan dan prosedur yang diberikan seorang pemimpin.oleh karenanya menciptakan dan memelihara harmonisasi lingkungan internal yang sepenuhnya melibatkan dirinya dalam pencapaian tujuan sangat penting dibangun oleh seorang pemimpin. Dengan kata lain, kepemimpinan hendaknya mampu mengarahkan organisasi dalam kesatuan gerak untuk mencapai tujuan organisasi sangat dibutuhkan agar pegawai memahami tujuan organisasi, membangun komunikasi yang efektif, sehingga tindakan yang dilakukan terkoordinasi dengan baik searah dengan tujuan organisasi.

\section{Pelibatan/keterlibatan Orang (Involvement of People)}

Orang pada semua tingkatan adalah inti sebuah organisasi dan pelibatan penuh mereka memungkinkan kemampuannya dipakai untuk kemanfaatan organisasi. Keterlibatan seluruh pegawai pada semua tingkatan memungkinkan seluruh potensinya untuk dimanfaatkan bagi keuntungan organisasi. Hal ini berguna agar pegawai termotivasi dalam inovasi dan kreativitas organisasi, sehingga berkontribusi bagi perbaikan yang berkelanjutan.

Peran orang tua dalam pembentukan motivasi dan penguasaan diri anak sejak dini merupakan modal besar bagi kesuksesan anak di sekolah. Peran orang tua terdiri dari: orang tua dapat mendukung perkembangan intelektual anak dan kesuksesan akademik anak dengan memberi mereka kesempatan dan akses ke sumber-sumber pendidikan seperti jenis sekolah yang dimasuki anak atau akses ke perpustakaan, multi media seperti internet dan televisi pendidikan. Orang tua dapat membentuk perkembangan kognitif anak dan pencapaian akademik secara langsung dengan cara terlibat langsung dalam aktivitas pendidikan mereka. Orang

11 Wahyuli Lius Zen, "Manajemen Peningkatan Mutu Lembaga Pendidikan Islam," AlMufida 1, no. 1 (2016): 133. 
tua juga mengajarkan anak norma dalam berhubungan dengan orang dewasa dan teman sebaya yang relevan dengan suasana kelas. ${ }^{12}$

1. Pendekatan Proses (Process Approach)

Penilaian atas prinsip ini akan meningkatkan efisiensi penggunaan sumberdaya finansial, dan lebih fokus kepada prioritas yang memberikan nilai tambah.

2. Pendekatan sistem pada manajemen (System Approach to Management)

Mengetahui, memahami, dan mengelola permasalahan atau proses yang saling terkait sebagai sistem sehingga memberikan sumbangan pada efektivitas dan efisiensi organisasi dalam mencapai tujuannya. Hal ini bermanfaat bagi penyelarasan proses yang memberikan hasil terbaik dan menjamin konsistensi.

3. Perbaikan Berkelanjutan (Continual Improvement)

Perbaikan berkelanjutan terhadap organisasi secara menyeluruh hendaknya dijadikan tujuan tetap dari organisasi. Hal ini terutama bermanfaat bagi peningkatan kinerja seiring peningkatan kapasitas organisasi, dan memberikan fleksibilitas dalam merespon peluang dengan cepat.

4. Pengambilan Keputusan Berdasarkan Fakta (Factual Approach to Decision Making)

Keputusan yang efektif didasarkan pada analisis data dan informasi. Pendekatan ini bermanfaat untuk meningkatkan kualitas pengambilan keputusan, efektivitas keputusan, dan pertanggungjawaban/evaluasi.

5. Hubungan Pemasok yang saling menguntungkan (Mutually Beneficial Supplier Relationships)

Sebuah organisasi dan pemasoknya saling bergantung dan suatu hubungan yang saling menguntungkan untuk meningkatkan kemampuan keduanya dalam menciptakan nilai. Jika hubungan antarorganisasi saling menguntungkan, maka akan tercipta sinergi untuk meningkatkan manfaat yang lebih optimal. Hal ini berguna dalam meningkatkan kerjasama yang saling menguntungkan, dan meningkatkan fleksibilitas dalam merespon setiap perubahan. ${ }^{13}$

\footnotetext{
12 Zen, 137.

13“'Sistem Manajemen Mutu," wikiapbn.org, accessed May 6, 2021, https://www.wikiapbn.org/sistem-manajemen-mutu/.
} 
Senada dengan konsep ISO tersebut, Sallis juga mengemukan faktor utama dalam implementasi TQM pada suatu organisasi adalah sebagai berikut:

a. Leadership (Kepemimpinan)

b. Teamwork (Kerja Tim)

c. Knowledge Management (Respon terhadap informasi)

d. Tools and Technique (Alat / cara mengidentifikasi dan memecahkan masalah secara kreatif)

e. Benchmarking (Sebagai jembatan kesenjangan posisi sekarang dan yang ingin diwujudkan)

f. Measurement (ukuran)

g. Budgeting (Penganggaran)

h. Strategy (strategi mutu yang jelas)

i. Framework (Kerangka Kerja)

j. $\quad$ Self Assessment (Penilaian Diri) ${ }^{14}$

Pada awalnya, manajemen cenderung hanya diimplementasikan pada duniabisnis atau perusahaan. Namun pada perkembangannya tidak dapat dipungkiri bahwa semua bdang organisasi membutuhkan adanya manajemen yang baik untuk mencapai visidan misi secara efektif dan efisien. Sebagaimana telah penulis kemukakan sebelumnya bahwa inti dari kegiatan manajemen ini adalahminimal planning, organizing, Leadership dan controlling. Dengan mengacu pada prinsip utama manajemen ini maka sangatlah penting untuk diperhatikan bahwa planning menjadi dasar dan starter dalam menjalankan manajemen. Oleh karena itu visi dan misi organsiasi dapat terwujud sebagian besar tergantung pada strategic planning.

Sebagaimana dikemukakan oleh Gary Dessler berikut:

A strategic plan is the company s plan for how it will match its internal strengths and weaknesses with external opportunities and threats in order to maintain a competitive advantage. The essence of strategic planning is to ask, Where are we now as a business, where do we want to be, and how should we get there? The manager then formulates specific (human resources and other) plans to take the company from where it is now to where he or she wants it to be. ${ }^{15}$

Fungsi dari rencana strategis dalam sebuah perusahaan adalah mencocokkan kekuatan-kekuatan dan kelemahan-kelemahan internal dengan peluang dan tantangan luar agar mampu bersaing.esensinya adalah bertanya, di mana posisi kita sekarang, kita posisi apa yang hendak dicapai, bagaimana untuk mencapainya kemudian seorang manajer memformulasikan secara spesifik

\footnotetext{
${ }^{14}$ Sallis, Total Quality Management in Education, 67-144.

${ }^{15}$ Gary Dessler, Human Resource Management, 13th ed. (New Jersey: Pearson Education, Inc., 2013), 73.
} 
tentang SDM, dan lain sebagainya. Langkah-langkah ini dapat diaplikasikan dalam dunia pendidikan sehingga akan berpengaruh pada mutu pendidikan itu sendiri.

Adapun dalam proses manajemen strategis ini adalah (1) defining the business and developing a mission,(mendefinisikan bisnis dan mengembangkan misi), (2) evaluating the firms internal and external strengths, weaknesses, opportunities, and threats, (mengevaluasi kekuatan,kelemahan, peluang dan ancaman perusahaan baik yang adadi dalam maupun di luar perusahaan) formulating a new business direction, ,(merumuskan arah baru bisnis) (4) translating the mission into strategic goalsand (menterjemahkan misi ke dalam tujuan-tujuanstrategis) (5) formulating strategies or courses of action.(merumuskan strategi-strategi atau pelajaran tindakan) Step (6) and step (7) entail implementing and then evaluating the strategic plan.(langkah keenam dan ketujuh adalah mengimplementasikan rencana strategis serta mengevaluasinya). ${ }^{16}$

\section{SMP Berbasis Pesantren dan Integrated Total Quality Management}

Sekolah umum yang notabenenya bukan sekolah keagaman pada era globalisasi sangat dirasakan kurang mampu membekali peserta didik dengan karakter dan moral yang kuat. Penghayatan dan pengamalan ajaran agama menjadi ciri khas pokok pendidikan pesantren yang sudah diakui mampu membentuk karakter para santrinya. Sehngga kurikulum nasional yang terbaru ini menekankan penguatan pendidikan karakter. Namun hakikatnya secara realistis dan cukup efektfi pendidkan karakter yang sesungguhnya sudah dilaksanakan di pesantren-pesantrenn sejak lama. ${ }^{17}$

SMP Berbasis Pesantren adalah sebuah lembaga pendidikan formal yang berada di lingkungan pesantren. Pesantren Based Schools, a program that attempt to integrate the advantages of the school education system with the organization of education in Islamic boarding schools. ${ }^{18}$ di zaman sekarang ini semua lini kehidupan tidak terlepas dari peran teknologi dan komunikasi tak terkecuali dunia pendidikan. Hal ini sangata terasa saat ini ketika masa pandemi Covid 19 yang melanda dunia sangat bergantung pada kemahiran dan keterampilan dalama mengaplikasikan teknologi yang ada. Akan tetapi fungsi mendasar dalam pendidkan yaitu menanamkan karakter dan nilai-nilai moral tidak dapat tergantikan oleh teknologi.

${ }^{16}$ Dessler, 73-76.

17 Ahmad Yusuf, "Kompetensi Pedagogik Guru Pendidikan Agama Islam Dalam Implementasi Kurikulum 2013 Pada SMP Berbasi Pesantren” (IAIN Kudus, 2020), 65.

18 Ahmad Yusuf, "PESANTREN AND CHALLENGES OF MODERNITY A Critical View Of Pesantren - Based School Model for Education in Modernity," QUALITY 7, no. 2 (2019): 147, https://doi.org/10.21043/quality.v7i2.6269. 
of course the development of information technology strongly supports the effectiveness and efficiency of learning process, administration and so forth. But we have to care about one thing that is fading away in such situations, is character and culture. Characters and cultures cannot be transformed through technological advances. The fascinated attitudes of information technology, that is increasingly opening the gates to moral degradation, especially among millennials. They are very clever in arguing with insights from browsing on the internet that may not be accountable, but morale, character, religiosity increasingly eroded and even almost extinct. So it is not surprising that vulnerable acts of anarchist, brutal without thinking wisely in acting and tend to neglect their environment. $^{19}$

Pendidikan Pesantren semakin menunjukkan ketangguhannya dan konsistennya dalam menanamkan karakter pada para santrinya. Hal ini terbukti dengan animo masyarakat yang semakin meningkat mempercayakan pendidikan putra-putrinya di pesantren. Ada beberapa unsur pokok yang harus terpenuhi oleh sebuah lembaga pendidikan yang disebut pesantren. Zamakhsyari Dhofier memberikan kriteria pesantren ini dengan mengemukakan lima komponen pokok yang harus terpenuhi sehingga lembaga tersebut dapat dikategorikan sebagai pondok pesantren. Adapun komponen pokok tersebut adalah pondok, masjid, santri, pengajaran/pembelajaran kitab kuning dan adanya seorang kyai.

1. Pondok

Pada dasarnya pesantren merupakan sebuah model pendidikan yang diselenggarakan di asrama atau pondok di mana para santri tinggal dan mendapatkan bimbingan, arahan,teladan dan berbagai pelajaran dari sang kyai yang biasanya juga tinggal di kompleks asrama. Adanya pondok sebagai tempat tinggal santri ini menjadi salah satu ciri model pendidikan pesantren sebagai diferensiasi dari lembaga pendidikan pada umumnya.

2. Masjid

Memperhatikan fungsi utama dari masjid yaitu sebagai tempat berkumpulnya kaum muslim untuk melaksanakan ibadah secara berjamaah, masjid menjadi sangat efektif sebagai pusat pendidikan para santri. Oleh karennya masjid menjadi bagian tak terpisahkan dari pesantren. Dengan istilah lain masjid sebagai manifestasi universalisme dari sistem pendidikan Islam. Dengan adanya masjid para santri akan lebih berkesempatan untuk mempraktekkan ajaran-ajaran agama dalam kehidupan sehari-hari. Dalam waktu-waktu tertentu masjid juga berfungsi sebagai central pengajian umum para santri.

\footnotetext{
${ }^{19}$ Yusuf, 147-48.
} 
3. Pengajaran/pembelajaran Kitab kuning (kitab klasik islami)

Pesantren identik dengan pembelajaran kitab kuning, yaitu suatu literatur yang otoritatif para ulama dalam Bahasa Arab. Biasanya ditulis dengan tanpa harakat (gundhul) sehingga membutuhkan ilmu nahwu-shorof untuk mampu membaca dan memaknainya dengan baik. Kitab kuning menjadi ciri khas pesantren dapat dikelompokkan menjadi delapan macam pelajaran yaitu nah\{wu-s\{orof, fiqh, us\{ul fiqh, h\{adits, tafsir, $\operatorname{tauh}\{i>d$, tas\}awwufletika, dan cabang-cabang ilmu lain seperti tarikh/sejarah dan balaghah.

4. Santri

Istilah lain dari murid/peserta didik dalam pesantren adalah santri. Istilah santriini sangat erat terkait dengan kyai(seorang guru yang mengasuh pesantren). Disebut kyai karena memiliki sejumlah santri yang belajar padanya dan mautinggal di pondok. Simbol lain yang spesifik melekat pada kata santri yaitu sesorang yang mendalami atau mengkaji kitab-kitab kuning di pesantren. Adapun santri ini terbagi atas dua jenis menurut cara bagaimana mereka mengikuti pengajaran di pesantren yaitu:

a) Santri mukim, adalah santri yang belajar di pesantren dan tinggal di pondok pesantren dalam waktu tertentu

b) Santri kalong, adalah sejumlah santri yang mengikuti pembelajaran di pesantren yang berasaldari daerah sekitar pesantren sehingga setelah pembelajaran selesai mereka kembali pulang, tidak tinggal di pesantren.

5. Kyai

Predikat lain dari kyai biasanya juga sebagai pengasuh pesantren. Kyai menjadi komponen pokok pesantren karena padaumumnya sebagai pendiri pesantren itu sendiri. Peranan kyai, pandangan-pandangannya dalam berbagai hal dalam pesantren sangatlah urgen karena menjadi sosok sentral kemajuan atau kemunduran pesantren. Kemampuan kyai secara keilmuan dan pengelolaan pesantren menjadi tumpuan eksistensi pesantrennya. ${ }^{20}$

Integrasi kurikulum pesantren dengan kurikulum umum sekolah menjadi idealitas pendidikan SMP Berbasis Pesantren. Hal ini bukanlah sebuah usaha yang mudah. Madrasah sekalipun yang notabenenya sebagai solusi untuk menjembatani dikotomi ilmu dirasa masih belum manunjukkan hasil yang maksimal. Padahal konsep integrasi kurikulum ini menjadi sebuah tuntutan masyarakat, namun juga sebagai kebutuhan adminsitratif pada lembaga pendidikan berbasispesantren. Hal

${ }^{20}$ Zamakhsyari Dhofier, Tradisi Pesantren, Studi Pandangan Hidup Kyai Dan Visinya Mengenai Masa Depan Indonesia, 15th ed. (Jakarta: LP3ES, 2015), 79-99. 
ini dikarenakan lembaga-lembaga tersebut belum menerapkan manajemen integrasi kurikulum secaraoptimal. $^{21}$

Terkait dengan integerasi pesantren pada sekolah umum, agar dapat terwujud dengan efektif menurut Abudin Nata dalam Ahmad Yusuf menawarkan beberapa konsep yang perlu diperhatikan, yaitu:

1. Integrasi yang dibangun adalah integrasi yang saling mengisi dan melengkapi antara sistem pendidikan nasional 9sekolah umum) dan pendidikan pesantren. Mengkolaborasikan masing-masing keunggulan antara keduanya menjadi halpenting. Peantren identik dengan pendidikan agama tafaqquh fiddin dan karakter akhlakul karimah semestinya diadopsi oleh sekolah umum, sebaliknya pendidikan umum yang basanya memeiliki keunggulan bidang pengetahuan umum, teknnologi serta bahasa asing juga diaopsi dalam pengembangan pesantren. Keunggulan-keunggulan kedua model pendidikan tersebut menjadi prinsip dasar untuk mendesain model kurkulum yang terintegrasi pesantren-sekolah umum.

2. Pembelajaran nilai-nilai akhlak mulia menjadi living value yang kentaldi pesantren diimplementasikan dalam pendidikan nasional (sekuolah umum). Hal ini dapat terealisasi dengan konsitensi dan pengawasan berbagai pihak pesantren dan sekolah dengan menciptakan lingkungan yang sarat dengan keteladanan dari kyai, guru dan warga sekolah lainnya.

3. Pesantren memiliki kultur kepeloporan, kerakyatan dan kesahajaan yang terbukti mampu mempertahankan eksistensinya dalam merespon modernisasi dan globalisasi. Kultur ini patut untuk diterapkan dalam prinsip pengelollahn pendidikan nasional sehingga pendidikan kreatif, inovatif dan berkarakter dapat terwujud. $^{22}$

\section{Integrated Total Quality Management SMP Berbasis Pesantren}

Sistem manajemen mutu yang diimplementasikan di SMP Berbasis Pesantren ini adalah sebuah manajemen yang saling mengisi dan melengkapi antara manajemen pondok pesantren dan sekolah. Meski terlihat dominasi pesantren masih sangat kental dalam berbagai pengambilan keputusan. Pada umumnya pesantren memposisikan seorang kyai adalah sebagi sosok sentral dalam kepemimpinan.oleh karena itu tidak heran apabila kyai sudah berkehendak maka seluruh jajaran manajemen enggan untuk menolak atau atau tidak setuju, meskipun secara analisis belum efektif.

21 M. Islam, "Management of Islamic Boarding School Curriculum Integration in Improving the Quality of Madrasah Education," HALAQA: ISLAMIC EDUCATION JOURNAL 5, no. 1 (n.d.): 64, https://doi.org/doi: 10.21070/halaqa.v5vi1i.1325.

${ }^{22}$ Yusuf, "Kompetensi Pedagogik Guru Pendidikan Agama Islam Dalam Implementasi Kurikulum 2013 Pada SMP Berbasi Pesantren," 66-67. 
Sebagaimana dikemukakan oleh Abdurrahman Mas'ud dalam Faisal kamal bahwa kyai adalah sebagai role model yang dianggap sebagai manifestasi kepemimpinan sosok Nabi Muhammad SAW. Kyai memiliki karisma yang mampu mempengaruhi para santri dan masyarakatnya. ${ }^{23}$ Dengan demikian sangat jelas bahwa pengaruh kyai sangat besar daripada pengaruh dan peran kepala sekolah. Hal demikian inilah yang terjadi di lingkungan SMP Islam Ar-Rais yang notabene Berbasis Pesantren. Kendati demikian, pengasuh pesantren sangat memikirkan kualitas peserta didik baik dalam pembelajaran ataupun sebagai lulusan. Oleh karenanya dalam beberapa hal yang dilakukan oleh pengasuh ponpes guna mewujudkan visi dan misi pendidikan adalah:

1. Memberikan peraturan santri di sekolah dan di pondok pesantren

2. Menentukan kegiatan-kegiatan kesiswaan agar tidak terjadi tumpang tindih antara sekolah dan pondok pesantren

3. Mendominasi menentukan kebijakan anggaran keuangan/pembiayaan dalam penyelenggaraan pendidikan di sekolah

4. Seleksi dan penempatan staf/guru sepenuhnya oleh Pesantren.

5. Peran sekolah sangat terbatas,sehingga MBS yang diharapka oleh pemerintah tidak dapat diterapkan.

Pada dasarnya setiap sekolah diharapkan menerapkan sistem manajemen berbasis sekolah. Yaitu sebuah sistem manajemen yang melibatkan seluruh komponen stakeholder seperti orang tua,peserta didik, staf abik akademikmaupun non akademik untuk berperan aktif dalam mewujudkan sekolah yang efektif. Sebagaimana ungkapan Bashimane Mollootimile \& Thulani Zengele berikut: "The SBM approach, according to its proponents, requires different stakeholders such as parents, learners and the school staff, both academic and non-academic, to bring their respective strengths in a concerted manner to the joint task of ensuring school effectiveness." 24

Sebagai sekolah formal diharapakan SMP mengimplementasikan sistem Manajemen Berbasis Sekolah. Dengan Manajemen Berbasis Sekolah (MBS) ini diharapkan sekolah dan para guru diberikan kesempatan untuk mengembangkan kompetensinya secara profesional, baik secara kelompok maupun secara indivdual.pengembangan profesionalita ini yang sangat berpotensi membawa kemajuan sekolah karena berhubungan erat dengan guru dan peserta didik yang hakikatnya adalah subyek pendidikan. Mollootimile \& Zengele menjelaskan:

23 Faisal Kamal, Charismatic Leadership: Peranan,Pemikiran Dan PandanganHidup KH.Muntaha Wonosobo, ed. M. Yusuf Amin Ngroho (Wonosobo: Bimalukar Kreativa, 2021), 22.

${ }^{24}$ Bashimane Mollootimile and Thulani Zengele, "THE ADVENT OF SCHOOL BASED MANAGEMENT IN THE 21ST CENTURY," E-Bangi: Journal of Social Sciences and Humanites 10, no. 2 (2015): 172. 
Through SBM, teachers may decide to develop professionally on an ongoing basis with the aim to improve themselves as individuals. Professional development has a positive bearing towards school goals as it empowers those closest to the learners and the teachers who in turn empower the learners and ultimately the community at large. ${ }^{25}$

Kondisi sistem manajemen yang terkesan masih belum tertata dan simbang yang mampu meningkatkan mutu pendidikan maka sangat perlu untuk dilakukan terobosan implementasi pengembangan model Integrated Total Quality Management di SMP Berbasis Pesantren. Tantangan terbesar dalam sistem ITQM ini bukanlah pada konsepnya, namun lebih mengarah pada kesiapan pada sekolah dan pesantren serta yayasan itu sendiri.

Sebagaimana T. S. Hlongwane and R. Mestry, dalam Muhammad Yusuf, dkk mengemukakan beberapa faktor besar yang memepengaruhi keberhasilan implementasi ITQM ini.

The important thing to consider in implementing TQM is the obstacles that might be encountered. Several factors can influence this, namely the lack of constant goals so that organizations are hampered from adopting quality as management, the existence of short-term thinking, the existence of individual evaluations that are only carried out through consideration scale or annual report. To overcome that obstacles and challenges, a strong commitment is needed to build a quality culture in vocational schools, especially from among principals, teachers, students, and external stakeholders through industrial organizational integration and resource-based view theory providing a useful framework for analyzing comprehensively and systematically industrial sector related to competitive advantage. ${ }^{26}$

Dalam mengembangkan sekaligus membangun sebuah model Integrated Total Management di SMP Berbasis Pesantren sangat perlu memperhatikan beberapa aspek-aspek potensi yang dimiliki sekolah dan pesantren. Sekolah Berbasis Pesantren memiliki tiga ranah manajemen yaitu; manajemen sekolah/SMP, manajemen Pondok Pesantren, dan manajemen Yayasan. Ketiga ranah manjemen tersebut harus menyatukan visi dan misi untuk mencapai tujuan yang sama yaitu perbaikan mutu lulusan yang akan dihasilkan.

${ }^{25}$ Mollootimile and Zengele, 174.

${ }^{26}$ Muhammad Yusuf, Muhammad Amir Masruhin, and Hasbi Sjamsir, "Integrated Quality Management Practices in the Technical and Vocational Education in Indonesia: A Lesson from the SMKN 7 Samarinda, East Kalimantan Province," ATLANTIS PRESS:Advances in Social Science, Education and Humanities Research 224 (2019): 92. 
Ketiga unsur Pesantren, Sekolah dan Yayasan penting membangun keselarasan tujuan, serta visi dan misi yang hendak dicapai mengelola pendidikan, kebijakan yang saling mengisi, kurikulum pesantren dan sekolah yang terintegrasi, sarana prasarana yang memadai, SDM yang berkompeten, peserta didik, pembiayaan, lingkungan dan evaluasi. Ini sangatlah perlu untuk disepakati pertama kali sebelum masuk pada model integerasi manajemen. Hal ini tentu untuk menghindari duplikasi program atau ketumpang-tindihan (overlapping) kebijakan. Dengan demikian tercipta model manajemen yang mengintegerasikan semua proses dalam organisasi dibawah satu kerangka lengkap dan utuh, di mana setiap sistem mampu menjalankankan perannya secara maksimal dan tetap terkoordinasi satu sama lain untuk mewujudkan visi dan misi yang sama. ${ }^{27}$

Model manajemen Pesantren, Yayasan dan Sekolah senantiasa berupaya melaksanakan prinsip-prinsip manajemen yang berorientasi peningkatan mutu, yaitu quality planning, quality organizing, quality actuating dan quality controlling dalam setiap proses manajemen. Ketiga manajemen tersebut saling terkoordinasi dengan baik sesuai dengan peran dan fungsinya dalam meningkatkan mutu mencakup 8 Standar Nasional Pendidikan, yaitu: standar pengelolaan, standar kompetensi lulusan(SKL), standar isi, standar proses, standar penilaian, standar pendidik dan tenaga kependidikan(tendik), standar sarpras, dan standar pembiayaan Adapun strategi logis yang dapat diaplikasikan antara lain sebagai berikut:

1. Menyelaraskan visi,misi,budaya dan program-program dalam setiap divisi

2. Menetapkan dan membiasakan sistem PDCA (Plan, Do, Check, and Action) di berbagai proses manajemen

3. Menentukan target kinerja

4. Mengadopsi dan mengadaptasikan standar-standar sistem manajemen yang fleksibel mengarah pada peningkatan mutu seperti ISO 9001 dan lainnya

5. Mengaplikasikan standar-standar sistem manajemen secara terintegrasi,bersinergi, saling mengisi danmelengkapi untuk menghindari duplikasi progam dan keijakan.

6. Mengintegrasikan dokumentasi yang serupa secara bertahap

7. Mengintegrasikan tujuan-tujuan umum dari masing-masing unsur.

8. Menentukan kendali dan penanggung jawab manajemen dalam satu manajer

9. Mengukur kinerja sacara transparan

10. Mencari peluang secara terus menerus agar model integrasi manajemen semakin efsien dan efektif. ${ }^{28}$

27 "Strategi Implementasi Integrasi Sistem Manajemen," Indonesiasafetycenter.org, accessed June 18, 2021, https://indonesiasafetycenter.org/strategi-implementasi-integrasi-sistemmanajemen/.

28 "Strategi Implementasi Integrasi Sistem Manajemen." 
Model Hipotetik Integrated Total Quality Management SMP Berbasis Pesantren secara prosedural dapat dideskripsikan dalam gambar bagan berikut:

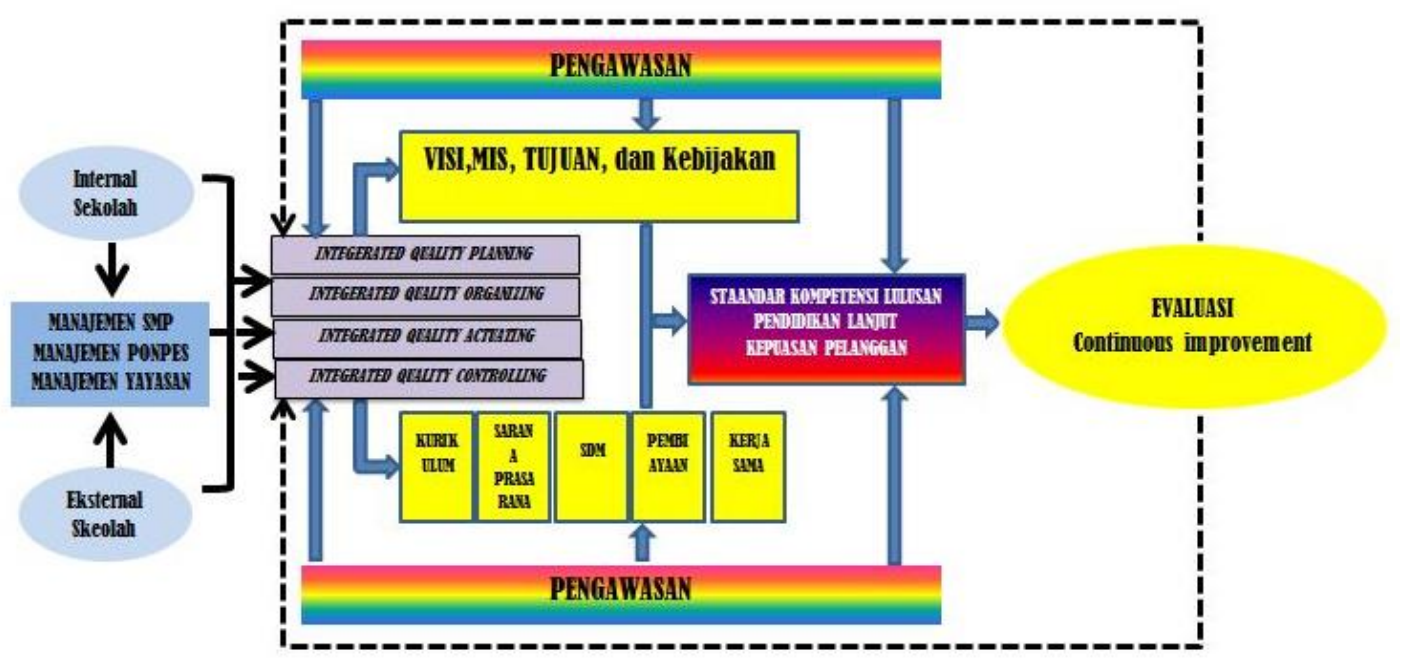

Gambar 1: Model Integrated Total Management SMP Berbasis Pesantren

\section{KESIMPULAN}

Total Quality Management (TQM) adalah sebuah konsep dan pendekatan filosofis dan metodologis dalam manajemen yang tidak lain bertujuan untuk peningkatan mutu dengan prinsip perbaikan terus menerus secara progresif dengan memaksimalkan segaa potensi yang dimiliki suatu lembaga/organisasi.

Total Integrated Management padaSMP Berbasis Pesantren menjadi alternatif yang layak untuk dipertimbangkan dan dilaksanakan. Dengan mengintegerasikan sekaligus mensinergikan sistem manajemen pesantren, sekolah dan dikuatkan oleh yasan menjadi kekuatan penuh dalam mengembangkan dan terus memperbaiki mutu pendidikan yang diselenggarakan. Melalui proses atau sistem pengelolaan yang kooperatif, komprehensif, sistemik, dan sistematik dapat mengakselerasikan ketercapaian tujuan/visi yang sudah dirumuskan. Proses manajemen tidak dapat mengesampingkan kerjasama sosial antara dua orang atau lebih secara formal dengan bantuan sumber daya yang mendukungnya. Prinsip dasar implementasi manajemen ini adalah kooperatif demi terwujudnya cita-cita bersama yang telah dirumuskan dalam visi dan misi secara efektif dan efisien.

Adapun fungsi dari model Integrated Total Quality Management (ITQM) adalah untuk mengintegrasikan masing-masing keunggulan manajemen yang ada di pesantren dengan yang ada di sekolah umum yang terakomodir dengan baik oleh manajemen yayasan. Sehingga tercipta sebuah kondisi integrasi-inter konektif yang saling bersinergi dalam meningkatkan mutu pendidikan. Sebagai imbasnya adalah terciptanya sebuah model manajemen yang harmonis antara manajemen Pesantren, Yayasan dan Sekolah dalam meningkatkan mutu 
pendidikan yang berfokus pada 8 Standar Nasional Pendidikan secara berkelanjutan, berorientasi pada kepuasan pelanggan (internal customer dan external customer). ITQM SMP Berbasis Pesantren mejadi sebuah terobosan revolusioner untuk meningkatkan efisiensi pemanfaatan seluruh potensi yang ada, meningkatkan keadilan dan kesempatan bagi peserta didik untuk mencapai hasil yang maksimal melalui rangkaian kegiatan pendidikan yang dikelola secara integritas dalam mencapai tujuan, meningkatkan motivasi pada kinerja guru dan aktifitas siswa karena adanya dukungan positif yang diciptakan dalam kegiatan pengelolaan kurikulum, SDM dan Sarana \& prasarana serta meningkatkan pastisipasi masyarakat untuk menunjang eksistensi lembaga yang relevan dengan kebutuhan masyarkat/stakeholder.

\section{DAFTAR PUSTAKA}

Dessler, Gary. Human Resource Management. 13th ed. New Jersey: Pearson Education, Inc., 2013.

Dhofier, Zamakhsyari. Tradisi Pesantren, Studi Pandangan Hidup Kyai Dan Visinya Mengenai Masa Depan Indonesia. 15th ed. Jakarta: LP3ES, 2015.

Gaspersz, Vincent. Total Quality Management. Jakarta: PT Gramedia Pustaka Utama, 2008.

Islam, M. "Management of Islamic Boarding School Curriculum Integration in Improving the Quality of Madrasah Education." HALAQA: ISLAMIC EDUCATION JOURNAL 5, no. 1 (n.d.): 63-72. https://doi.org/doi: 10.21070/halaqa.v5vi1i.1325.

Kamal, Faisal. Charismatic Leadership: Peranan,Pemikiran Dan PandanganHidup KH.Muntaha Wonosobo. Edited by M. Yusuf Amin Ngroho. Wonosobo: Bimalukar Kreativa, 2021.

Mason A. Carpenter. Management Principles. Creative Commons by-nc-sa 3.0, n.d. http://creativecommons.org/licenses/by-nc-sa/3.0/).

Mollootimile, Bashimane, and Thulani Zengele. "THE ADVENT OF SCHOOL BASED MANAGEMENT IN THE 21ST CENTURY.” E-Bangi: Journal of Social Sciences and Humanites 10, no. 2 (2015): 172-84.

Nasution, MN. Manajemen Mutu Terpadu. Jakarta: Ghalia Indonesia, 2000.

Prawirosentono, Suryadi. Filosofi Baru Tentang Manajemen Mutu Terpadu. Jakarta: PT.Bumi Aksara, 2002.

Sallis, Edward. Total Quality Management in Education. 3rd ed. London: Kogan Page Ltd, 2002.

wikiapbn.org. "Sistem Manajemen Mutu.” Accessed May 6, 2021. https://www.wikiapbn.org/sistem-manajemen-mutu/.

Indonesiasafetycenter.org. "Strategi Implementasi Integrasi Sistem Manajemen." Accessed June 18, 2021. https://indonesiasafetycenter.org/strategiimplementasi-integrasi-sistem-manajemen/.

Sugiyono. Metode Penelitian Pendidikan; Pendekatan Kuantitatif, Kualitatif, Dan $R \& D$. Bandung: Alfabeta, 2016.

Sulipan. "Manajemen Mutu Pendidikan.” wordpress.com, n.d. 
Yusuf, Ahmad. "Kompetensi Pedagogik Guru Pendidikan Agama Islam Dalam Implementasi Kurikulum 2013 Pada SMP Berbasi Pesantren.” IAIN Kudus, 2020.

- "PESANTREN AND CHALLENGES OF MODERNITY A Critical View Of Pesantren - Based School Model for Education in Modernity." QUALITY 7, no. 2 (2019): 140-55. https://doi.org/10.21043/quality.v7i2.6269.

Yusuf, Muhammad, Muhammad Amir Masruhin, and Hasbi Sjamsir. "Integrated Quality Management Practices in the Technical and Vocational Education in Indonesia: A Lesson from the SMKN 7 Samarinda, East Kalimantan Province." ATLANTIS PRESS:Advances in Social Science, Education and Humanities Research 224 (2019).

Zen, Wahyuli Lius. "Manajemen Peningkatan Mutu Lembaga Pendidikan Islam." AlMufida 1, no. 1 (2016): 123-40. 